B. Niroula / Our Nature (2003) 1: 10-14

\title{
Comparative Effects of Industrial Effluents and sub- metropolitan Sewage of Biratnagar on Germination and seedling growth of Rice and Blackgram
}

\author{
Bhabindra Niroula \\ Department of Botany, P.G. Campus, Biratnagar.
}

\begin{abstract}
Comparative effects of effluents from six major industries viz. Diesel Power House, Hetaunda Iron and Steel, Hulas Wire, Himalaya Soap and Chemicals, Leather Industry, Shah Udyog and submetropolitan Sewage of Biratnagar on germination and seedling growth of rice and black gram were studied. Effluent of Himalaya Soap and Chemicals showed toxic lethal effect on both the test crops. On germination rice remained more sensitive and susceptible to the toxic effects of industrial effluents but black gram proved to be more tolerant. Effluents of Diesel power House and Shah Udyog remained toxic for seedling growth of black gram as their effects were significant while Leather Industry effluent showed toxic effect on rice for germination as well as seedling growth.
\end{abstract}

\section{Introduction}

Growing industrial establishments without proper attention on pollution control measures have resulted adverse impact on the local environment in the city like Biratnagar (Lat N 26 $29^{\prime}$, long E 87 $16^{\prime}$; altitude $72 \mathrm{~m}$ ). Due to availability of various infrastructure facilities several types of industries viz., Jute, Textile, Sugar, Leather, Soap. Plastic, Match, Iron rod, Galvanized iron products; stainless steel, liquors, biscuits, oil seed extraction mills etc. operate in Biratnagar. These industries as well as rapidly expanding Biratnagar sub metropolitan city discharge their untreated wastes directly into the natural environments (water courses, land, air) thereby polluting them (Sharma and Rijal 1988, Niroula 1996, Dahal et al. 1997, Jha and Niroula 1998, Shrestha 2000).

The use of wastewaters (industrial effluents as well as municipal Sewage) for irrigation has emerged in the recent past as an important way of utilization of wastewater taking the advantage of the presence of considerable quantities of nitrogen and phosphorus along with some other essential elements. Other advantage of wastewater irrigation includes an important aspect of pollution removal. The pollutants are partly taken up by the plants and partly transformed in the soil without causing any damage. Nevertheless, the use of waste waters for agriculture is marred by several constraints due to various problems like soil salinity, interaction of chemical constituents of the wastes with the uptake of nutrients and changes in soil property and micro flora (Goel and Kulkarni 1994). This necessitates a detailed scientific study before any specific waste can be used for irrigation for a particular crop with particular soil and climate. Since crop plants are increasingly being exposed to the effluent discharge in the industrial area, an attempt has been done to study the comparative effects of six major industrial effluents and sub metropolitan Sewage of Biratnagar on germination and seedling growth of rice (Oryza sativa L.) and Blackgram [Vigna mungo (L.) Hepper]. 


\section{B. Niroula / Our Nature (2003) 1: 10-14}

\section{Materials and Methods}

Wastewaters from the Sub-metropolitan Sewage of Biratnagar and following industries were selected for the study.

- Diesel Power House (producing electricity)

- Hetaunda Iron \& Steel (manufacturing iron rods for building \& road construction)

- Hulas Wire (manufacturing galvanized iron products)

- Himalaya Soap \& Chemicals (producing different types of soaps).

- Leather Industry.

- Shah Udyog (Textile Industry)

The industrial effluents were collected in polythene containers directly from the outlet of the factories while sub metropolitan Sewage was collected from the discharge point of sewer located at the bank of Singhia River. Colour (visual appearance), $\mathrm{pH}$, dissolved oxygen (Winkler's method) and solute particles (Zobel et al.1987) were recorded immediately after sample collection. The collected wastewaters were stored in dark at room conditions for future uses.

Germination experiments were carried out in petridishes (dia $9 \mathrm{~cm}$ ) in triplicates under room conditions. Two third portion of each petridish was filled with sand soaked in undiluted effluent/ Sewage and each petridish contained 25 seeds. Control experiment, which was performed with tap water. Seven and four days old seedlings from rice and blackgram petridish respectively were taken randomly and their respective longest root and shoot lengths were measured for each treatment and control. Data of seedlings were analyzed statistically using student's t test.

\section{Results and Discussion}

Himalaya Soap and Chemicals had the highest amount of dissolved solutes (145.1g/1), lowest dissolved oxygen ( $0.9 \mathrm{mg} / \mathrm{l})$ and alkaline $\mathrm{pH}$ (11) range in comparison to other industrial effluents and Sub metropolitan sewage (Table 1). Hulas Wire effluent had acidic $\mathrm{pH}$ (4) and the values ranges 6 to 8 in other industrial effluents and Sub metropolitan sewage. Similarly dissolved oxygen and dissolved solutes ranges $0.83 \mathrm{mg} / \mathrm{l}$ to $1.8 \mathrm{mg} / \mathrm{l}$ and $0.2 \mathrm{~g} / \mathrm{l}$ to $3.7 \mathrm{~g} / \mathrm{l}$ respectively while the values were $3.2 \mathrm{mg} / \mathrm{l}$ and $0.1 \mathrm{~g} / \mathrm{l}$ for tap water.

Effluent of Himalaya Soap \& Chemicals inhibited germination completely for both the tested seeds. In rice, germination is greatly inhibited by the effluent of Leather Industry and limited to only $5 \%$ but it stimulates the blackgram. (Table 2). Effluents of Diesel Power House had considerable inhibitory effects but effluent of Hetaunda Iron \& Steel, Hulas Wire and Shah Udyog had negligible

inhibitory effect on germination. Submetropolitan sewage promoted germination slightly in rice. Except Himalaya Soap and chemicals, other industrial effluents had no considerable negative effect on seed germination of blackgram. Indeed, the effluents of Hetaunda Iron \& Steel, Leather Industry and Shah Udyog had promontory on blackgram.

In seedling growth of blackgram, root growth is not significantly affected by all the tested Industrial effluents and Sub-metropolitan Sewage (Table 3). Shoot growth is significantly inhibited by the effluents of Diesel Power House (Hypocotyl F= $\mathrm{p} \leq 0.01$, Epicotyl $\mathrm{F}=\mathrm{p} \leq 0.05$ ). Shah Udyog $(F=p \leq 0.01)$ and Hulas Wire $(F=p$ $\leq 0.05$ ) effluents inhibited the hypocotyl growth significantly. Other effluents/sewage had no significant effect on growth of shoot (hypocotyl + epicotyl) in blackgram. Whole seedling growth of rice (root + shoot) is significantly affected by the effluents of Leather Industry $(\mathrm{F}=\mathrm{P} \leq 0.01)$. 


\section{B. Niroula / Our Nature (2003) 1: 10-14}

However, other effluents/ sewage had no significant effect on rice seedling.

Effluent of Himalaya Soap and Chemicals had lethal toxic effect on both the test crops. On germination rice remained more sensitive and susceptible to the toxic effect of industrial effluents while blackgram proved to be more tolerant. Leather Industry effluent had significant inhibitory effect on germination and seedling growth of rice but it remained negligible on blackgram for both the parameters. For blackgram seedling, Diesel Power House and Shah Udyog effluents had significant inhibitory effect while they had little or no impact on germination and seedling growths on rice.

Plants show different degree of responses with effluents at different stages of development and also the magnitude of toxicity depends upon species (Chapagain, 1995, Niroula 1996, Shrestha 2000).

Ghimire and Bajracharya (1996) reported significant differences in the sensitivity of four types of vegetable seeds (Brassica juncea, B. oleracea, B.rapa and Raphanus sativus) of a single family Brassicaceae) to the effluent of carpet dyeing, tannery and steel industries.

Gupta and Chapagain (1999) observed significantly different effect of polluted water of Dhobikhola on Pisum sativum and
Lepidium sativum. Seed germination and seedling growth of all tested vegetables were highly sensitive to the effluents but the nature of the sensitivity varied with the type of effluents and seed types. Jha and Niroula (1998) showed differential sensitivity to various industrial effluents and municipal sewage on germination and dry weight increase on rice and blackgram. In this study also, rice and backgram showed differential sensitively to the tested effluents / sewage on germination and seedling growth.

Reduction in germination and seedling growth in the test crops by the industrial effluents in the present study may be due to osmotic inhibition of water absorption and / or heavy metal toxicity inhibiting the functions of essential enzymes (Jerome and Ferguson 1972, Mayer and Poijakoff Mayber 1982). To understand the exact nature and causes of different industrial effluents / sewage on the tested plants it still awaits detail physico-chemical analysis and further research in different growth parameters.

\section{Acknowledgements}

Author is grateful to Department of Botany, Post Graduate Campus Biratnagar, and T.U. for providing laboratory facilities.

Table 1. General features of the industrial effluents, Sub metropolitan sewage and tap water

\begin{tabular}{|c|l|l|c|c|c|}
\hline S.N. & \multicolumn{1}{|c|}{ Effluents/Sewage } & Colour & $\begin{array}{c}\text { Dissolved } \\
\text { oxygen (mg/l) }\end{array}$ & $\begin{array}{c}\text { Dissolved } \\
\text { solutes (g/l) }\end{array}$ & $\mathrm{pH}$ \\
\hline 1 & Diesel power House & Grey & 1.26 & 3.7 & 8 \\
\hline 2 & Hetaunda Iron \& Steel & Watery & 1.86 & 0.2 & 8 \\
\hline 3 & Hulas Wire & $\begin{array}{l}\text { Reddish } \\
\text { Yellow }\end{array}$ & 2.90 & 1.8 & 4 \\
\hline 4 & $\begin{array}{l}\text { Himalaya Soap \& } \\
\text { Chemicals }\end{array}$ & Red & 0.90 & 145.1 & 11 \\
\hline 5 & Leather Industry & Blue & 1.53 & 0.5 & 6 \\
\hline 6 & Shah Udyog & Violet & 0.83 & 1.5 & 7 \\
\hline 7 & Sub-metropolitan Sewage & Black & 1.40 & 1.0 & 8 \\
\hline 8 & Tap Water & - & 3.20 & 0.1 & 7 \\
\hline
\end{tabular}


B. Niroula / Our Nature (2003) 1: 10-14

Table 2. Comparative effects of industrial effluents and Sub metropolitan sewage on percentage germination of rice and blackgram

\begin{tabular}{|c|l|c|c|}
\hline \multirow{2}{*}{ S.N. } & \multicolumn{2}{|}{ Effluents/Sewage } & \multicolumn{2}{|c|}{ Germination (\%) } \\
\cline { 3 - 4 } & & Rice & Blackgram \\
\hline 1 & Diesel Power House & 65 & 88 \\
\hline 2 & Hetaunda Iron \& Steel & 80 & 92 \\
\hline 3 & Hulas Wire & 78 & 86 \\
\hline 4 & Himalaya Soap \& Chemicals & 00 & 00 \\
\hline 5 & Leather Industry & 05 & 92 \\
\hline 6 & Shah Udyog & 80 & 94 \\
\hline 7 & Submetropolitan Sewage & 88 & 86 \\
\hline 8 & Tap Water (Control) & 85 & 88 \\
\hline
\end{tabular}

Table 3. Comparative effects of industrial effluents and Sub-metropolitan sewage on seedling growth $(\mathrm{cm})$ of rice 7 and blackgram 4 days

\begin{tabular}{|c|c|c|c|c|c|c|}
\hline \multirow{3}{*}{ S.N. } & \multirow{3}{*}{ Effluents/Sewage } & \multicolumn{2}{|c|}{ Rice } & \multicolumn{3}{|c|}{ Black gram } \\
\hline & & \multirow{2}{*}{$\begin{array}{l}\text { Root } \\
(\mathrm{cm})\end{array}$} & \multirow{2}{*}{$\begin{array}{l}\text { Shoot } \\
(\mathrm{cm})\end{array}$} & \multirow{2}{*}{$\begin{array}{l}\text { Root } \\
(\mathrm{cm})\end{array}$} & \multicolumn{2}{|c|}{ Shoot $(\mathrm{cm})$} \\
\hline & & & & & Hypocotyl & Epicotyl \\
\hline 1 & Diesel Power House & $5.2 \pm 1.2$ & $2.6 \pm 0.74$ & $2.2 \pm 0.61$ & $1.7 \pm^{\otimes} 0.53$ & $4.9 \pm \pm^{\otimes \otimes} 0.64$ \\
\hline 2 & $\begin{array}{l}\text { Hetaunda Iron \& } \\
\text { Steel }\end{array}$ & $5.3 \pm 0.97$ & $3.9 \pm 0.68$ & $3.1 \pm 0.55$ & $5.3 \pm 0.58$ & $9.1 \pm 1.3$ \\
\hline 3 & Hulas Wire & $5.7 \pm 1.0$ & $3.4 \pm 0.66$ & $3.3 \pm 0.75$ & $2.7^{\otimes \otimes} \pm 0.34$ & $6.5 \pm 0.70$ \\
\hline 4 & $\begin{array}{l}\text { Himalaya Soap \& } \\
\text { Chemicals }^{\#}\end{array}$ & - & - & - & - & - \\
\hline 5 & Leather Industry & $0.3^{\otimes} \pm 0.33$ & $0.1^{\otimes} \pm 0.14$ & $3.9 \pm 0.54$ & $4.6 \pm 0.53$ & $8.6 \pm 1.0$ \\
\hline 6 & Shah Udyog & $4.8 \pm 0.14$ & $2.5 \pm 0.40$ & $2.6 \pm 0.55$ & $2.0^{\otimes} \pm 0.34$ & $5.1 \pm 0.61$ \\
\hline 7 & $\begin{array}{l}\text { Sub-metropolitan } \\
\text { Sewage }\end{array}$ & 4.4 & $2.6 \pm 0.44$ & .49 & .42 & $8.0 \pm 0.71$ \\
\hline 8 & Tap Water (Control) & $5.3 \pm 1.0$ & $2.8 \pm 0.51$ & $4.0 \pm 0.56$ & $6.5 \pm 0.43$ & $9.8 \pm 0.93$ \\
\hline
\end{tabular}

\# Effluent of Himalaya Soap \& Chemicals had lethal effect.

${ }^{\otimes}$ Significant at $1 \%$ level.

$\otimes \otimes$ Significant at $5 \%$ level.

\section{References}

Chapagain, N. 1991. Physiological impact of Dhobikhola (Kathmandu) water pollution on Persicaria perfoliata L. leaves and germination of some vegetable seeds. M.Sc. Thesis, Central

Department of Botany, T.U. Kathmandu, Nepal.

Dahal, M., M. D. Kafle and D. Rijal 1997. Environmental impact assessment of Rani Biratnagar, ( Field work Report), Department of Botany, Post Graduate Campus, T.U. Biratnagar, Nepal.
Ghimire, S. K. and D. Bajracharya 1996. Toxicity effect of industrial effluents on seed germination and seedling growth of some vegetables. Ecoprint 3: 1-12.

Goel, P. K., S. M. Kulkami 1994. Effects of sugar factory waste on germination of Gram seed (Cicer aeritinum L.). Jour. of Environ. and Pollution 1: 35-53.

Gupta, V. N. P. and N. Chapagain 1999. Germination behaviour of some vegetable seeds as affected by polluted water of Dhobikhola (Kathmandu). Scientific World 1: 37-42. 
B. Niroula / Our Nature (2003) 1: 10-14

Jerome, G. and Ferguson 1972. The cycling of mercury through the environment. Water Res. 6: 989-1008.

Jha, S. and B. Niroula 1998. Effects of various industrial effluents and Municipal Sewage on germination and growth of rice and blackgram; T.U. Journal 21: 63-69.

Mayer, A. M. and A. Poljakoff Mayber 1982. The germination of seeds, Pergamon press, London.

Niroula, B. 1996. Evaluation of some effluents on germination and growth of Oryza sativa L.cv.

"Chaite-4" and Vigna mungo (L) Hepper. M.Sc. Thesis, Department of Botany, Post Graduate Campus, T.U. Biratnagar, Nepal.

Sharma, A. P. and A. Rijal 1988. Impact of industrial effluent on pollution of river and adjoining land. Project Report, National Committee for Man and Biosphere (MAB), Kathmandu, Nepal.
Shrestha, M. 2000. Effect of industrial and municipality sewage effluents on germination, growth and yield of Pea (Pisum sativum L.Var arkel). M.Sc. Thesis, Department of Botany, Post Graduate Campus, T.U. Biratnagar, Nepal.

Zobel, D. B., P. K. Jha, M. J. Behan and U. K. R. Yadav 1987. A practical manual for ecology. Ratna book Distributor, Kathmandu. 